\title{
Genetic forms of neurohypophyseal diabetes insipidus
}

Martin Spiess (Ph.D., Professor of Biochemistry) ${ }^{1}$, Nicole Beuret (M.Sc., Academic Technical Assistant) ${ }^{1}$, Jonas Rutishauser (M.D., Adjunct Professor of Medicine and Endocrinology Senior Consultant $)^{1,2^{*}}$

${ }^{1}$ University of Basel, Biozentrum, Klingelbergstrasse 50/70, CH-4056 Basel, Switzerland

${ }^{2}$ Kantonsspital Baden, Clinical Trial Unit, Im Ergel 1, CH-5405 Baden, Switzerland

* for correspondence; j.rutishauser@unibas.ch; phone +41-56-486 2514

Email addresses:

martin.spiess@unibas.ch nicole.beuret@unibas.ch j.rutishauser@unibas.ch 


\section{Abstract}

In the majority of cases, hereditary neurohypophyseal diabetes insipidus (DI) is a monogenic disorder caused by mutations in the $\underline{A V P}$ gene. Dominant transmission is by far the most common form. In these patients, symptoms develop gradually at various ages during childhood, progressing with complete penetrance to polyuria and polydipsia that is usually severe. In autosomal dominant neurohypophyseal DI (ADNDI), the mutant prohormone is folding deficient and consequently retained in the ER, where it forms amyloid-like fibrillar aggregates. Degradation by proteasomes occurs, but their clearance capacity appears to be insufficient. Postmortem studies in affected individuals suggest a neurodegenerative process confined to vasopressinergic neurons. Other forms of genetic neurohypophyseal DI include the very rare autosomal recessive type, also caused by mutations in the $\underline{A V P}$ gene, and complex multiorgan disorders, such as Wolfram syndrome. In all individuals where a congenital form of DI is suspected, including nephrogenic types, genetic analysis should be performed.

\section{Key Words}

Diabetes insipidus, neurogenic; neurohypophyseal, vasopressin; neurophysin; hereditary; copeptin

\section{Acknowledgments}

This work was supported by grants $31003 \mathrm{~A}-182519$ (to M.S.) and 31003A-113319 (to J.R.) from the Swiss National Science Foundation. 


\section{Introduction}

Polyuria, i.e. the production of $>45-50 \mathrm{ml}$ of hypotonic $(<300 \mathrm{mOsmol} / \mathrm{kg})$ urine per $\mathrm{kg}$ body weight and day under ad libitum fluid intake, is the hallmark of untreated diabetes insipidus (1, 2) (DI; Greek and Latin for "tasteless water flow"). If the thirst mechanism is intact, patients deprived of free access to fluids experience excessive thirst (polydipsia). DI results from disturbances in the antidiuretic system either at the hypothalamic/hypophyseal level (central or neurohypophyseal DI), or - in the case of nephrogenic DI - from insufficient response of the renal type 2 receptor (AVPR2) to the antidiuretic hormone arginine vasopressin (AVP). "Primary polydipsia" refers to a form of DI that results from physiologically suppressed AVP secretion due to excessive fluid intake, either because of alterations in the thirst mechanism (“dipsogenic DI”) or a psychologically motivated habit (“psychogenic DI”). In primary polydipsia as well as pituitary or nephrogenic DI with large fluid throughput, the renal urinary concentration capacity may be reduced due to partial washout of the corticomedullary osmogradient, potentially complicating the differential diagnosis based on measurements of urinary osmolality alone (3). Pregnancy-associated DI is caused by increased activity of a placental vasopressinase, leading to inadequately low circulating AVP concentrations. Vasopressinase-mediated, acute DI has also been observed after placental abruption (4).

Table 1 gives an overview over the differential diagnosis of DI. Both central and nephrogenic DI may have a genetic basis. This review will discuss the pathophysiology of the various forms of hereditary neurohypophyseal DI, focusing on clinical characteristics, the impact of mutations in the $\underline{A V P}$ gene on vasopressinergic neurons, and the role of the cellular quality control system with respect to water homeostasis.

\section{Historical aspects and early histopathological findings}


In 1841, the French physician L.-U. Lacombe was the first to describe hereditary DI in an extensive report on 29 clinical "observations" (5). Large DI family trees were subsequently published by German authors in the late $19^{\text {th }}$ and early $20^{\text {th }}$ century (68). During the Nazi period, a German textbook shockingly commented with respect to hereditary DI that “..... The reproduction of this variety of diabetics is equally undesirable. For as harmless as this constitutional anomaly may be under ordinary circumstances, as dangerous it might become for those participating in a war, for example." (translated from German by J.R. from (9)). Histopathological alterations in deceased patients with hereditary or "idiopathic" neurohypophyseal DI were acknowledged at about the same time (10) and later confirmed in several publications (11-15). The authors described paucity of magnocellular AVP-producing neurons and mild gliosis in the hypothalamic parvocellular and supraoptic nuclei, as evidenced by brain sections prepared post mortem. These findings suggested a degenerative process confined specifically to vasopressinergic neurons, constituting the basis for the "neurotoxicity hypothesis".

The genes encoding the human vasopressin and oxytocin preprohormones were cloned in 1985 (16), paving the way for the identification of the first mutation in the $\underline{A V P}$ gene (17) and its expression in cell culture experiments and transgenic animal models (18).

\section{Clinical presentation and differential diagnosis of hereditary diabetes}

\section{insipidus}

Table 2 gives an overview over the different forms of DI with a genetic background. If $\mathrm{DI}$ is a component of a rare multiorgan disease, such as Wolfram syndrome, signs and symptoms other than polyuria/polydipsia may prevail (see paragraphs 5.2 and 5.3 on syndromic DI below). However, in the majority of cases, the disorder is caused by mutations in the $\underline{A V P}$ gene. In the case of the very rare autosomal recessive form, polyuria may manifest acutely in the neonatal period $(19,20)$, putting 
the child in danger of severe, even life-threatening dehydration. This clinical feature may equally be observed in hereditary nephrogenic DI due to mutations in the AVPR2- or Aquaporin 2 - genes (21). In sharp contrast, symptoms in autosomaldominant neurohypophyseal DI (ADNDI) manifest later in childhood and develop gradually to polyuria that is usually severe $(3,18,22)$. There is no clear genotypephenotype correlation in ADNDI, with the exception that certain mutations resulting in partial signal cleavage in prepro-AVP-neurophysin II (NPII) tend to cause milder symptoms and later onset $(2,23-25)$ than mutations occurring in the NPII moiety or those abolishing signal cleavage completely $(26,27)$. The reason for this observation is most likely residual antidiuretic hormone secretion of fully cleaved, biologically active hormone until the vasopressinergic neurons have eventually been eliminated. Interestingly, the clinical presentation may vary considerably between families and even family members carrying the same mutation in the $\underline{\operatorname{AVP}}$ gene $(23,28,29)$. Another unexplained observation is that polyuria may regress with increasing age (29-31).

As in other forms of diabetes insipidus, children affected with ADNDI who are not properly treated or refused appropriate access to fluids develop failure to thrive, which may be reversed upon treatment with synthetic AVP (DDAVP) (19, 32-34). Another potential consequence of untreated chronic polyuria, be it due to neurogenic (35) or nephrogenic (36-38) DI, is dilation of the ureters and bladder (21), which predisposes to vesicoureteral reflux and ascending urinary tract infections, as well as secondary renal failure. The prevalence of these complications is unknown, but they may be more frequent in persistent nephrogenic DI, such as the inherited types, since treatment is less efficient than neurohypophyseal DI.

Diagnosis in all hereditary forms of DI should be established by medical history, clinical and laboratory testing and - if possible - genetic analysis. If a hereditary background is known or suspected, genetic analysis is always advised and may make strenuous clinical testing superfluous, particularly in children. Importantly, a 
negative family history does not rule out a genetic cause of $\mathrm{DI}$, as mutations may occur de novo $(39,40)$, or a previously asymptomatic recessive form may be present (41).

Polyuria must be differentiated from pollakisuria and should be quantified; if present, other causes such as uncontrolled diabetes mellitus, hypercalcaemia, or hypokalaemia must be excluded. Measurement of copeptin, the C-terminal glycopeptide of the AVP prohormone (Figure. 1), has proven very helpful to differentiate nephrogenic DI, neurohypophyseal DI, and primary polydipsia $(42,43)$. Copeptin is stoichiometrically cosecreted with AVP from the posterior pituitary and can thus serve as surrogate marker for vasopressin (44). Since copeptin, unlike vasopressin, is stable and reliably measured in serum or plasma, commercially available assays (e.g. ref. (45)) help circumvent the technically demanding AVP radioimmunoassays, which never entered clinical routine, or the commercially available AVP assays of questionable validity. In an adult patient presenting with a suggestive history and confirmed polyuria/polydipsia, an elevated unstimulated circulating copeptin level $>21.4$ pM establishes the diagnosis of nephrogenic DI (42, 43). If the copeptin concentration is lower, it is adequate in most cases to perform a stimulatory test, e.g. by water deprivation, hypertonic saline infusion (43) or arginine infusion (46).

\section{Monogenic neurohypophyseal diabetes insipidus: mutations in the $\underline{A V P}$} gene.

The $\underline{\text { AVP }}$ gene, located on chromosome 20p13 and separated from the homologous Oxytocin gene by a $\sim 12$ kilobase sequence, has three exons separated by two introns. The gene encodes prepro-vasopressin-neurophysin II, consisting of the 21 amino acid (aa) N-terminal signal peptide (SP), the nonapeptide AVP, the "carrier" protein neurophysin II (NPII) of 93 aa, and the C-terminal 39-aa glycopeptide, termed copeptin (Figure 1) (47). The latter is lacking in prepro-oxytocin-neurophysin I, which 
facilitated the development of an assay for highly specific detection and quantification of the antidiuretic capacity in the differential diagnosis of polyuric syndromes. Figure 2 depicts the regulated secretion of vasopressin from magnocellular neurons in the supraoptic and paraventricular hypothalamic nuclei. During synthesis at the ribosome, the nascent polypeptide chain is translocated into the lumen of the endoplasmic reticulum (ER). During translocation, the SP is cotranslationally cleaved. Subsequently, the prohormone AVP-NPII-copeptin folds in the ER lumen, which involves the binding of AVP into a binding pocket in NPII $(48,49)$, and is transported through the Golgi apparatus to the trans-Golgi network, where it is sorted into neurosecretory granules and cleaved into AVP, NPII and copeptin. Granules are axonally transported from the cell bodies to cell endings in the posterior pituitary. AVP, NPII and copeptin are cosecreted into the circulation by regulated secretion upon various stimuli, most notably hyperosmolality and hypovolaemia. While copeptin has been found to mediate granule sorting and regulated secretion (50), there is no known function for both copeptin and NPII after secretion into the circulation.

Since the first publication in 1991 (17), numerous mutations causing hereditary neurogenic diabetes insipidus have been reported. Currently, the public and professional domains of the Human Gene Mutation Database (HGMD, http://www.hgmd.cf.ac.uk) list 75 and 87 variants, respectively, most of them being missense/nonsense mutations. Deletions, indels and splice mutations account for a minority of reported cases. All mutations reported so far have occurred in the gene regions encoding the signal peptide, AVP, or neurophysin II (Figure 1). The disease is usually transmitted in a dominant fashion, but rarely, families with recessive phenotypes have been reported. Interestingly, in one Chinese family with autosomal dominant transmission of neurohypophyseal DI, no mutation could be identified in the $\underline{A V P}$ gene or its promoter, although linkage to a 7-centiMorgan interval on chromosome 20p13 was shown (51). 


\subsection{Autosomal dominant neurohypophyseal DI}

This is by far the most common form, accounting for $>90 \%$ of reported family trees. Its pathogenesis is discussed in detail in section 6 below.

\subsection{Autosomal recessive neurohypophyseal DI}

Four family trees with a recessive mode of inheritance have been reported so far. Affected members of two seemingly unrelated consanguineous Palestinian families from Texas (32) and Israel (19) were homozygous for a point mutation in the gene domain encoding AVP, replacing proline at position 7 by leucin (P7L). The mutant protein is correctly trafficked through and secreted from the cell (52), but its binding affinity to the renal receptor is decreased $\sim 30$-fold (32). In another consanguineous English family originating from Pakistan, hypernatraemia, serum hyperosmolality and low concurrent urine osmolality occurred in the index patient during the first few days of life (20). His physicians documented failure to thrive. The father of the proband and several relatives also had DI, with the onset of symptoms reported between 3 and 11 months. Genetic analysis revealed a large deletion of $\sim 10$ kilobases on both alleles in the index patient and other affected family members, encompassing most of the $\underline{A V P}$ gene, its regulatory sequences and the intergenic region between the $\underline{A V P}$ and oxytocin $(\underline{O T X})$ genes. This deletion likely abolishes transcription of the $\underline{A V P}$ gene. In a Canadian family without any history of $\mathrm{DI}$, the index patient was born to asymptomatic parents, presenting with polyuria, polydipsia and failure to thrive in the first months of life (41). Analysis of the $\underline{A V P}$ gene showed compound heterozygosity of the P7L mutation and a novel point mutation at the splice-acceptor site of intron 1.

In contrast to early-onset signs and symptoms in nephrogenic DI, affected individuals of all four families with recessive neurogenic DI were responsive to 
treatment with DDAVP. As noted above, the report by Bourdet et al. highlights the importance of genetic testing even in the absence of a family history.

\section{X-linked and syndromic forms of genetic neurohypophyseal DI}

\subsection{X-linked: the unidentified gene}

To date, one preliminary report on a family with $\mathrm{X}$-linked transmission has been published (53). Males develop DDAVP-sensitive DI as infants or during early childhood, and the extent of AVP deficiency varies (3). The responsible gene links to chromosome Xq28 but has not been identified. Importantly, both the $\underline{A V P}$ and $\underline{\text { AVPR2 }}$ genes harbor no mutations.

\section{$\underline{5.2 \text { Wolfram syndrome }}$}

DDAVP-responsive partial or severe DI (54) is a component of the Wolfram syndrome 1, or DIDMOAD (Diabetes Insipidus, Diabetes Mellitus, Optic Atrophy, sensorineural Deafness) (55). This rare, progressive neurodegenerative disorder is transmitted in an autosomal recessive fashion, with homozygous or compound heterozygous mutations occurring in the responsible Wolframin (WFS1) gene located on chromosome $4 p 16.1(56,57)$. Diagnostic criteria typically include only juvenile onset diabetes mellitus and progressive optic atrophy, but the diagnosis may be missed if the age criterion is used stringently (58), because symptoms may manifest after the age of 18 years. DI has been reported to be present in $29 \%$ (59) to $73 \%$ (60) of affected patients, occurring at a median age of $\sim 15$ years. Other clinical characteristics include renal tract abnormalities, psychiatric symptoms such as depression with a high suicide risk $(61,62)$, and neurological complications resulting from brain stem and cerebellar pathology, such as gait ataxia, horizontal nystagmus, dysarthria, or central apnoea. Manifestation of urinary tract and neurological disease may peak at age 20 and 30 years, respectively, depending on the genotype (58). 
Death occurs at a median age of 30 years (60) as a consequence of respiratory complications.

WFS1 encodes a calcium channel with 9 transmembrane domains across the ER membrane (57). The mutations are distributed throughout the gene without detectable hot spots, and may lead to degradation of aberrant mRNA or of unfolded wolframin (58). Wolframin deficiency causes ER stress and triggers apoptosis in neuronal and pancreatic beta cells (63).

\subsection{Neurohypophyseal DI in the context of malabsorptive diarrhoea}

Mutations in the proprotein convertase subtilisin/kexin type 1 ( $\underline{P C S K 1})$ gene have been identified in children with severe obesity, malabsorptive diarrhoea and various endocrine disorders $(64,65)$. This rare, complex gastrointestinal and endocrine syndrome is transmitted in an autosomal-recessive fashion. The PCSK1 gene is expressed mainly in the brain, adrenal gland and gastrointestinal tract, including the pancreas (https://www.ncbi.nlm.nih.gov/gene/5122\#gene-expression). It encodes proprotein convertase $1 / 3(\mathrm{PC} 1 / 3)$, a serine protease that processes prohormones synthesized in neuroendocrine and enteroendocrine cells, e.g. proinsulin or proopiomelanocortin (POMC), into mature peptides (66). Accordingly, endocrine and metabolic consequences of PC1/3 deficiency include hyperphagia (67), hypocortisolism, hypogonadotropic hypogonadism, impaired glucose tolerance (68), growth hormone deficiency, central hypothyroidism, and DDAVP-sensitive DI (65, 69, 70). DI typically manifests before the age of 5 years (70), with the average age of onset being approximately 18 months of age (65). These pathologies apparently are of hypothalamic/pituitary origin.

\section{Pathogenesis of autosomal-dominant neurohypophyseal diabetes insipidus} (ADNDI) 
Many $\underline{A V P}$ gene mutations associated with ADNDI have been studied in heterologous expression experiments using various cell lines, and a small number has been expressed in transgenic animals.

\subsection{ER retention and ER-associated degradation of folding-incompetent mutant AVP} precursor hormones

The ER represents the quality-control site in eukaryotic cells, permitting exit to the Golgi apparatus only to correctly folded proteins (71) (Figure 2). ER-resident chaperones, such as binding protein (BiP), calreticulin, or protein disulfide isomerase (PDI) associate with nascent polypeptides, facilitating the assumption of the correct three-dimensional conformation and preventing their aggregation. Prolonged association of misfolded proteins with chaperones, which are themselves resident in the ER due to an ER retention motif in their primary structure, results in ER retention and eventually retrotranslocation into the cytoplasm (72), where the mutant protein is hydrolyzed by the proteasome (see Figure 4 for more details). ER retention and ERassociated degradation (ERAD) has been demonstrated for multiple dominant proAVP variants, e.g. the $\Delta \mathrm{G} 227$ mutant, which abolishes cleavage of the signal peptide from the prohormone chain (27) (Figure 3), and other mutations occurring in the signal peptide or NPII moieties (73). Notably, a significant portion of wild type provasopressin is also substrate for proteasomal degradation, because retrotranslocation occurs apparently due to relatively inefficient folding, and because the preprohormone is synthesised in part into the cytosol due to relative targeting inefficiency of the signal sequence in (73).

The fact that in ADNDI only one allele carries a pathogenic mutation implicates a dominant-negative effect on the wild type counterpart, which eventually leads to the typical symptoms and histological findings described in paragraphs 2 and 3. Several mechanisms have been specifically implied in the pathogenesis of ADNDI. Since AVP prohormone molecules form homodimers (74), the mutant may hinder secretion 
of wild type molecules. There is experimental evidence for such interaction (75); however, this mechanism explains neither the progressive nature of the disease nor the available histopathological data and can thus not be solely responsible for them.

If the amount of proteins populating the ER exceeds its folding capacity, a number of pathways, collectively called the ER stress response or unfolded protein response (UPR), are activated (76-78), leading to increased expression of ER chaperones while generally repressing protein synthesis. In some instances, apoptotic pathways may become activated $(79,80)$. Stable expression of an ADNDI truncation mutant in a mouse neuroblastoma cell line (81) and in a transgenic knock-in mouse model (82) has been reported to cause cell death as evidenced by immunostaining; but it has been questioned by other researchers whether cytotoxicity is primarily responsible for the phenotype, as transgenic mice expressing the same truncation mutant have reproduced the phenotype even prior to neuronal loss, suggesting a functional defect preceding the neurotoxic effect of the pro-AVP mutant (83). Notably, apoptosis markers were detectable neither in the cell culture nor the mouse experiments. Rather, electron microscopic examination of vasopressinergic neurons in the DI mice revealed dilated ER cisternae containing large aggregations, as well as cell loss associated with autophagy, a lysosomal degradation mechanism (84). Whether autophagy should be viewed as epiphenomenon, a potentially reparative process, or - conversely - causative for neuronal cell death currently remains unclear.

\subsection{ER-associated fibrillar aggregation of mutant AVP prohormone}

It was observed in early immunofluorescence studies that dominant pro-AVP mutants form aggregates located in the ER (81). Our group has studied this process in detail. When expressed in COS fibroblast cells, mutant pro-AVP clusters in large structures, consisting of disulfide-linked provasopressin polymers (27). The aggregations accumulate progressively after transfection of cultured cells and are composed of amyloid-like fibrils formed by the AVP precursor (52). In this respect, and considering 
the apparent cell loss of vasopressinergic neurons in animal and post mortem human studies, ADNDI bears resemblance to neurodegenerative disorders characterized by amyloid aggregates. However, while in Parkinson's, Alzheimer's or Huntington's disease aggregations are cytosolic or extracellular, pro-AVP aggregation occurs in the ER.

ER chaperones co-localize with pro-AVP in the aggregates, as evidenced by immunohistochemistry and immunogold electron microscopy (Figure 5). Aggregates from pathogenic pro-AVP mutants are observed not only in transfected fibroblast and mouse neuronal cell lines, but also in vitro for the purified protein under oxidative conditions (52). Aggregate formation in the ER is abolished when the 16 cysteine residues of the prohormone (Figure 1) are replaced by serine, indicating that disulfide links are necessary to stabilize aggregates in the ER (52).

We explored the relation between pathological aggregate formation of ADNDI mutants and the physiological self-aggregation occurring in the trans-Golgi network. This process is essential in the formation of secretory granules containing regulated cargo proteins and has been proposed to represent the formation of "functional amyloids" (85). To identify the provasopressin sequences containing the potential for aggregate formation, a number of artificial scanning and deletion mutants were expressed in neuronal cell lines. Analysis by biochemical methods, immunohistochemistry and immunogold electron microscopy demonstrated that the same two prohormone domains, namely AVP at the $\mathrm{N}$-terminus and the C-terminal copeptin, independently confer ER aggregation as well as granule sorting and regulated secretion of the precursor (50) (Figure 6). These findings suggest that the pathological ER aggregation observed with ADNDI mutants represent an aberrant, mislocalised process that physiologically occurs in granule biosynthesis, supporting the "functional amyloid" hypothesis.

\section{ER-associated degradation plays a physiological role in water homoeostasis}


Recently, the unexpected observation was made that mice with inducible deficiency of the essential ERAD components Sel1L or Hrd1 (Figure 4), developed polyuria and polydipsia due to DDAVP-sensitive DI (86). Endogenous pro-AVP was retained in the ER in these animals and the phenotype manifested without initial neuronal cell death. In Sel1L-deficient mice (Figure 7) as well as in cultured cells lacking Sel1L or Hrd1, wild type pro-AVP formed the same fibrillar, ER-associated disulfide-linked aggregations as ADNDI mutants. These findings show that pro-AVP is a physiological ERAD substrate, confirming and extending earlier findings of proteasomal degradation of mutant and wild type pro-AVP (73) and demonstrating the role of ER-associated degradation in maintaining physiological fluid homoeostasis. If transferred to the human, the data from mouse studies and experiments with cultured cells suggest that in ADNDI the capacity of the degradation machinery in vasopressinergic cells seems to be exceeded.

\section{Conclusion}

To differentiate the various aetiologies of the polyuria/polydipsia syndrome, clinical characteristics, personal and family history of affected individuals along with laboratory testing are key. In any person presenting with DI and a positive family history or childhood onset, even in the absence of affected family members, genetic analysis should be performed, focusing primarily on the $\underline{A V P}-, \underline{A V P R 2}-$ and

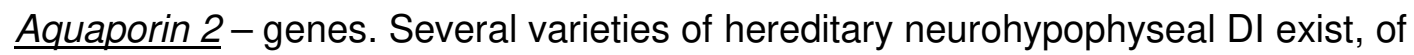
which the autosomal-dominant form is by far the most common.

\section{Practice Points}

- Autosomal dominant neurohypophyseal DI manifests in childhood, and symptoms develop gradually

- In contrast, acute dehydration in the perinatal and infant period may be lifethreatening in congenital nephrogenic DI 
- Polyuria and polydipsia are the main clinical manifestations, but failure to thrive and mental retardation may result from repeated episodes of dehydration in children with untreated DI of any aetiology

- Always seek genetic testing (sequence analysis of the $\underline{A V P}$ - , $\underline{A V P R 2}$ - or Aquaporin 2-genes, depending on clinical characteristics) if a positive family history and/or childhood manifestation is present

\section{Research Agenda}

- Study the role of ERAD in the pathogenesis of other disorders associated with protein aggregation

- Evaluate treatment options for such diseases by enhancing ERAD capacity

- Identify the mechanism of cell death and role of autophagy in ADNDI

- Identify the gene causing X-linked neurogenic DI

- Characterize the pathomechanism in neurohypophyseal DI associated with PCSK1 mutations.

\section{References}

(1) Robertson GL. Antidiuretic hormone. Normal and disordered function. Endocrinol Metab Clin North Am 2001;30: 671-694, vii.

(2) Christ-Crain M, Bichet DG, Fenske WK et al. Diabetes insipidus. Nature Reviews Disease Primers 2019;5:1-20. doi:10.1038/s41572-019-0103-2

(3) Robertson GL. Diabetes insipidus: Differential diagnosis and management. Best Pract Res Clin Endocrinol Metab 2016;30: 205-218.

(4) Wallia A, Bizhanova A, Huang W et al. Acute diabetes insipidus mediated by vasopressinase after placental abruption. J Clin Endocrinol Metab 2013;98: 881-886. (5) Lacombe LU. De la polydipsie. L'Expérience 1841;203-208: 305-391. 
(6) Weil A. Über die hereditäre Form des Diabetes insipidus. Virchows Arch 1884;90: 70-95.

(7) Weil A. Über die hereditäre Form des Diabetes insipidus. Archiv für klinische Medizin 1908;93: 180-200.

(8) Gänsslen F. Über Diabetes insipidus. Klin Wochenschr 1924;3: 22-23.

(9) Hanhart E. Die Erbpathologie des Diabetes insipidus. In: Just G, editor. Handbuch der Erbbiologie des Menschen. Berlin: Julius Springer; 1940. p. 798-823.

(10) Gaupp R. Über den Diabetes insipidus. Zeitschr für die gesamte Neurologie und Psychiatrie 1941;171: 514-546.

(11) Blotner H. Primary or idiopathic diabetes insipidus: a system disease. Metabolism 1958;7: 191-200.

(12) Braverman LE, Mancini JP \& Mc Goldrick DM. Hereditary idiopathic diabetes insipidus. A case report with autopsy findings. Annals of Internal Medicine 1965;63: 503-508.

(13) Green JR, Buchan GC, Alvorg EC \& Swanson AG. Hereditary and idiopathic types of diabetes insipidus. Brain 1967;90: 707-714.

(14) Nagai I, Li CH, Hsieh SM et al. Two cases of hereditary diabetes insipidus, with an autopsy finding in one. Acta Endocrinologica 1984;105: 318-323.

(15) Bergeron C, Kovacs K, Ezrin C \& Mizzen C. Hereditary diabetes insipidus: an immunohistochemical study of the hypothalamus and pituitary gland. Acta Neuropathologica 1991;81: 345-348.

(16) Sausville E, Carney D \& Battey J. The human vasopressin gene is linked to the oxytocin gene and is selectively expressed in a cultured lung cancer cell line. Journal of Biological Chemistry 1985;260: 10236-10241.

$(17)^{\star}$ Ito M, Mori $\mathrm{Y}$, Oiso $\mathrm{Y}$ \& Saito $\mathrm{H}$. A single base substitution in the coding region for neurophysin II associated with familial central diabetes insipidus. Journal of Clinical Investigation 1991;87: 725-728. 
(18) Rutishauser J, Beuret N, Prescianotto-Baschoing C \& Spiess M. Hereditary neurohypophyseal diabetes insipidus. In: Igaz P, Patócs A, editors. Genetics of Endocrine Diseases and Syndromes. Cham: Springer Nature Switzerland AG; 2019. p. 299-315.

(19) Abu Libdeh A, Levy-Khademi F, Abdulhadi-Atwan M et al. Autosomal recessive familial neurohypophyseal diabetes insipidus: onset in early infancy. European Journal of Endocrinology 2010;162: 221-226.

(20)* Christensen JH, Kvistgaard H, Knudsen J et al. A novel deletion partly removing the AVP gene causes autosomal recessive inheritance of early-onset neurohypophyseal diabetes insipidus. Clinal Genetics 2013;83: 44-52.

(21) Bichet DG \& Bockenhauer D. Genetic forms of nephrogenic diabetes insipidus (NDI): Vasopressin receptor defect (X-linked) and aquaporin defect (autosomal recessive and dominant). Best Pract Res Clin Endocrinol Metab 2016;30: 263-276. (22) Christensen JH \& Rittig S. Diabetes Insipidus. Genetic Diagnosis of Endocrine Disorders: Elsevier; 2016. p. 93-101.

(23) McLeod JF, Kovács L, Gaskill MB et al. Familial neurohypophyseal diabetes insipidus associated with a signal peptide mutation. Journal of Clinical Endocrinology and Metabolism 1993;77: 599A-599G.

(24) Siggaard C, Christensen JH, Corydon TJ et al. Expression of three different mutations in the arginine vasopressin gene suggests genotype-phenotype correlation in familial neurohypophyseal diabetes insipidus kindreds. Clinical Endocrinology 2005;63: 207-216.

(25) Toustrup LB, Kvistgaard H, Palmfeldt J et al. The Novel Ser18del AVP Variant Causes Inherited Neurohypophyseal Diabetes Insipidus by Mechanisms Shared with Other Signal Peptide Variants. Neuroendocrinology 2018;106: 167-186.

(26) Rutishauser J, Böni-Schnetzler M, Böni J et al. A novel point mutation in the translation initiation codon of the pre-pro-vasopressin-neurophysin II gene: cosegregation with morphological abnormalities and clinical symptoms in autosomal 
dominant neurohypophyseal diabetes insipidus. Journal of Clinical Endocrinology and Metabolism 1996;81: 192-198.

$(27)^{\star}$ Beuret N, Rutishauser J, Bider MD \& Spiess M. Mechanism of endoplasmic reticulum retention of mutant vasopressin precursor caused by a signal peptide truncation associated with diabetes insipidus. J Biol Chem 1999;274: 18965-18972. (28) Repaske DR, Medlej R, Gültekin EK et al. Heterogeneity in clinical manifestation of autosomal dominant neurohypophyseal diabetes insipidus caused by a mutation encoding $\mathrm{Ala}^{-1} \rightarrow \mathrm{Val}$ in the signal peptide of the arginine vasopressin/neurophysin II/copeptin precursor. Journal of Clinical Endocrinology and Metabolism 1997;82: 5156.

(29) Rutishauser J, Kopp P, Gaskill MB et al. A novel mutation (R97C) in the neurophysin moiety of prepro-vasopressin-neurophysin II associated with autosomaldominant neurohypophyseal diabetes insipidus. Molecular Genetics and Metabolism 1999;67: 89-92.

(30) Heppner C, Kotzka J, Bullmann C et al. Identification of mutations of the arginine vasopressin-neurophysin II gene in two kindreds with familial central diabetes insipidus. Journal of Clinical Endocrinology and Metabolism 1998;83: 693-696. (31) Christensen JH \& Rittig S. Familial neurohypophyseal diabetes insipidus - an update. Seminars in Nephrology 2006;26: 209-223.

$(32)^{*}$ Willcutts MD, Felner E \& White PC. Autosomal recessive familial neurohypophyseal diabetes insipidus with continued secretion of mutant weakly active vasopressin. Human Molecular Genetics 1999;8: 1303-1307.

(33) Nijenhuis M, van den Akker EL, Zalm R et al. Familial neurohypophysial diabetes insipidus in a large Dutch kindred: effect of the onset of diabetes on growth in children and cell biological defects of the mutant vasopressin prohormone. Journal of Clinical Endocrinology and Metabolism 2001;86: 3410-3420.

$(34)^{\star}$ Brachet C, Birk J, Christophe C et al. Growth retardation in untreated autosomal dominant familial neurohypophyseal diabetes insipidus caused by one 
recurring and two novel mutations in the vasopressin-neurophysin II gene. European Journal of Endocrinology 2011;164: 179-187.

(35) Wheeler JS \& Adelson WJ. Pituitary diabetes insipidus associated with progressive urinary tract dilatation. The Journal of urology 1964;92: 64-67.

(36) Zatuchni J, Armento DF \& Menzel PH. Pitressin-resistant diabetes insipidus and diabetes mellitus and bilateral hydronephrosis. The American journal of the medical sciences 1964;247: 445-450.

(37) McDill BW, Li S-Z, Kovach PA et al. Congenital progressive hydronephrosis (cph) is caused by an S256L mutation in aquaporin-2 that affects its phosphorylation and apical membrane accumulation. Proc Nat Acad Sci USA 2006;103: 6952-6957. (38) Zheng K, Xie Y \& Li H. Congenital Nephrogenic Diabetes Insipidus Presented With Bilateral Hydronephrosis and Urinary Infection: A Case Report. Medicine 2016;95: e3464-e3464.

(39) Rutishauser J, Kopp P, Gaskill MB et al. Clinical and molecular analysis of three families with autosomal dominant neurohypophyseal diabetes insipidus associated with a novel and recurrent mutations in the vasopressin-neurophysin II gene. European Journal of Endocrinology 2002;146: 649-656.

(40) Joshi S, Brandstrom P, Gregersen N et al. Novel de novo AVPR2 Variant in a Patient with Congenital Nephrogenic Diabetes Insipidus. Case Rep Nephrol Dial 2017;7: 130-137.

(41) Bourdet K, Vallette S, Deladoëy J \& Van Vliet G. Early-onset central diabetes insipidus due to compound heterozygosity for AVP mutations. Hormone Research in Pediatrics 2016;85: 283-287.

(42) Timper K, Fenske W, Kühn F et al. Diagnostic Accuracy of Copeptin in the Differential Diagnosis of the Polyuria-polydipsia Syndrome: A Prospective Multicenter Study. Journal of Clinical Endocrinology and Metabolism 2015;100: 2268-2274.

(43) Fenske W, Refardt J, Chifu I et al. A Copeptin-Based Approach in the Diagnosis of Diabetes Insipidus. N Engl J Med 2018;379: 428-439. 
(44) Balanescu S, Kopp P, Gaskill MB et al. Correlation of Plasma Copeptin and Vasopressin Concentrations in Hypo-, Iso-, and Hyperosmolar States. Journal of Clinical Endocrinology and Metabolism 2011;96: 1046-1052.

(45) Morgenthaler NG, Struck J, Alonso C \& Bergmann A. Assay for the measurement of copeptin, a stable peptide derived from the precursor of vasopressin. Clinical Chemistry 2006;52: 112-119.

(46) Winzeler B, Cesana-Nigro N, Refardt J et al. Arginine-stimulated copeptin measurements in the differential diagnosis of diabetes insipidus: a prospective diagnostic study. Lancet (London, England) 2019;394: 587-595.

$(47)^{\star}$ Spiess M, Friberg M, Beuret $\mathrm{N}$ et al. Role of protein aggregation and degradation in autosomal dominant neurohypophyseal diabetes insipidus. Mol Cell Endocrinol 2020;501: 110653, doi:110610.111016/j.mce.112019.110653.

(48) Wu CK, Hu B, Rose JP et al. Structures of an unliganded neurophysin and its vasopressin complex: Implications for binding and allosteric mechanisms. Protein Sci 2001;10: 1869-1880.

(49) De Bree FM, Van Der Kleij AAM, Nijenhuis M et al. The Hormone Domain of the Vasopressin Prohormone is Required for the Correct Prohormone Trafficking Through the Secretory Pathway. J Neuroendocrinol 2003;15: 1156-1163.

$(50)^{\star}$ Beuret N, Hasler F, Prescianotto-Baschong C et al. Amyloid-like aggregation of provasopressin in diabetes insipidus and secretory granule sorting. BMC Biology 2017;15: 1-14.

(51) Ye L, Li X, Chen Y et al. Autosomal dominant neurohypophyseal diabetes insipidus with linkage to chromosome 20p13 but without mutations in the AVP-NPII gene. Journal of Clinical Endocrinology and Metabolism 2005;90: 4388-4393. (52) Birk J, Friberg MA, Prescianotto-Baschong C et al. Dominant pro-vasopressin mutants that cause diabetes insipidus form disulfide-linked fibrillar aggregates in the endoplasmic reticulum. J Cell Sci 2009;122: 3994-4002. 
(53) Habiby R, Robertson GL, Kaplowitz PB \& Rittig S. A novel X-linked form of familial neurohypophyseal diabetes insipidus [abstract]. Journal of Investigative Medicine 1996;44: 341A.

(54) Thompson CJ, Charlton J, Walford S et al. Vasopressin Secretion in the DIDMOAD (Wolfram) Syndrome. Q J Med 1989;71: 333-345.

(55) Wolfram DJ \& Wagener HP. Diabetes mellitus and simple optic atrophy among siblings: report of four cases. Mayo Clin Proc 1938;13: 715-718.

(56) Strom TM, Hörtnagel K, Hofmann S et al. Diabetes insipidus, diabetes mellitus, optic atrophy and deafness (DIDMOAD) caused by mutations in a novel gene (wolframin) coding for a predicted transmembrane protein. Human Molecular Genetics 1998;7: 2021-2028.

(57) Inoue H, Tanizawa $\mathrm{Y}$, Wasson $\mathrm{J}$ et al. A gene encoding a transmembrane protein is mutated in patients with diabetes mellitus and optic atrophy (Wolfram syndrome). Nature Genetics 1998;20: 143-148.

(58) de Heredia ML, Clèries R \& Nunes V. Genotypic classification of patients with Wolfram syndrome: insights into the natural history of the disease and correlation with phenotype. Genet Med 2013;15: 497-506.

(59) Chaussenot A, Bannwarth S, Rouzier C et al. Neurologic features and genotypephenotype correlation in Wolfram syndrome. Ann Neurol 2011;69: 501-508.

(60) Barrett TG, Bundey SE \& Macleod AF. Neurodegeneration and diabetes: UK nationwide study of Wolfram (DIDMOAD) syndrome. Lancet (London, England) 1995;346: 1458-1463.

(61) Swift RG, Perkins DO, Chase CL et al. Psychiatric disorders in 36 families with Wolfram syndrome. Am J Psychiat 1991;148: 775-779.

(62) Swift RG, Polymeropoulos MH, Torres R \& Swift M. Predisposition of Wolfram syndrome heterozygotes to psychiatric illness. Molec. Psychiat 1998;3: 86-91.

(63) Delprat B, Maurice T \& Delettre C. Wolfram syndrome: MAMs\&apos; connection? Cell Death Dis 2018;9: 364. 
(64) Jackson RS, Creemers JW, Ohagi S et al. Obesity and impaired prohormone processing associated with mutations in the human prohormone convertase 1 gene. Nature Publishing Group 1997;16: 303-306.

(65) Martín MG, Lindberg I, Vargas RSS et al. Congenital Proprotein Convertase 1/3 Deficiency Causes Malabsorptive Diarrhea and Other Endocrinopathies in a Pediatric Cohort. Gastroenterology 2013;145: 138-148.

(66) Hoshino A \& Lindberg I. Peptide biosynthesis: prohormone convertases $1 / 3$ and 2. San Rafael, CA: Morgan \& Claypool Life Sciences Pubslishers; 2012.

(67) Farooqi IS, Volders K, Stanhope R et al. Hyperphagia and early-onset obesity due to a novel homozygous missense mutation in prohormone convertase $1 / 3$. J Clin Endocrinol Metab 2007;92: 3369-3373.

(68) O'Rahilly S, Gray H, Humphreys PJ et al. Brief report: impaired processing of prohormones associated with abnormalities of glucose homeostasis and adrenal function. N Engl J Med 1995;333: 1386-1390.

(69) Yourshaw M, Solorzano-Vargas RS, Pickett LA et al. Exome Sequencing Finds a Novel PCSK1 Mutation in a Child With Generalized Malabsorptive Diarrhea and Diabetes Insipidus. Journal of Pediatric Gastroenterology and Nutrition 2013;57: 759767.

(70) Pépin L, Colin E, Tessarech M et al. A New Case of PCSK1Pathogenic Variant With Congenital Proprotein Convertase 1/3 Deficiency and Literature Review. Clin Endocrinol Metab 2018;104: 985-993.

(71) Araki K \& Nagata K. Protein folding and quality control in the ER. Cold Spring Harb Perspect Biol 2011;3: a007526.

(72) Berner N, Reutter K-R \& Wolf DH. Protein Quality Control of the Endoplasmic Reticulum and Ubiquitin-Proteasome-Triggered Degradation of Aberrant Proteins: Yeast Pioneers the Path. Annu Rev Biochem 2018;87: 751-782. 
(73) Friberg MA, Spiess M \& Rutishauser J. Degradation of wild-type vasopressin precursor and pathogenic mutants by the proteasome. J Biol Chem 2004;279: 19441-19447.

(74) De Bree FM \& Burbach JPH. Structur-function relationships of the vasopressin prohormone domains. Cell Molecul Neurobiol 1998;18: 173-191.

(75) Ito M, Yu RN, Jameson JL \& Ito M. Mutant vasopressin precursors that cause autosomal dominant neurohypophyseal diabetes insipidus retain dimerization and impair the secretion of wild-type proteins. Journal of Biological Chemistry 1999;274: 9029-9037.

(76) Schröder M \& Kaufman RJ. The mammalian unfolded protein response. Annu Rev Biochem 2005;74: 739-789.

(77) Wang S \& Kaufman RJ. The impact of the unfolded protein response on human disease. J Cell Biol 2012;197: 857-867.

$(78)^{\star}$ Sun Z \& Brodsky JL. Protein quality control in the secretory pathway. J Cell Biol 2019;266: 3171-3187.

(79) Oyadomari S, Koizumi A, Takeda K et al. Targeted disruption of the Chop gene delays endoplasmic reticulum stress-mediated diabetes. J Clin Invest 2002;109: 525532.

(80) Oyadomari S \& Mori M. Roles of CHOP/GADD153 in endoplasmic reticulum stress. Cell Death Differ 2004;11: 381-389.

(81) Ito M \& Jameson JL. Molecular basis of autosomal dominant neurohypophyseal diabetes insipidus. Cellular toxicity caused by the accumulation of mutant vasopressin precursors within the endoplasmic reticulum. Journal of Clinical Investigation 1997;99: 1897-1905.

(82) Russell TA, Ito M, Ito $M$ et al. A murine model of autosomal dominant neurohypophyseal diabetes insipidus reveals progressive loss of vasopressinproducing neurons. J Clin Invest 2003;112: 1697-1706. 
(83) Hayashi M, Arima H, Ozaki N et al. Progressive polyuria without vasopressin neuron loss in a mouse model for familial neurohypophysial diabetes insipidus. $A m J$ Physiol (Regul Integ Compr Physiol) 2009;296: R1641-1649.

$(84)^{*}$ Hagiwara D, Arima $\mathrm{H}$, Morishita $\mathrm{Y}$ et al. Arginine vasopressin neuronal loss results from autophagy-associated cell death in a mouse model for familial neurohypophysial diabetes insipidus. Cell Death Dis 2014;5: e1148.

(85) Maji SK, Perrin MH, Sawaya MR et al. Functional amyloids as natural storage of peptide hormones in pituitary secretory granules. Science 2009;325: 328-332.

$(86)^{\star}$ Shi G, Somlo DRM, Kim GH et al. ER-associated degradation is required for vasopressin prohormone processing and systemic water homeostasis. J Clin Invest 2017;127: 3897-3912.

${ }^{*}$ Asterisked for particular relevance. 


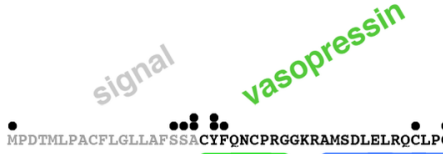

exon 1

exon 2

exon 3 

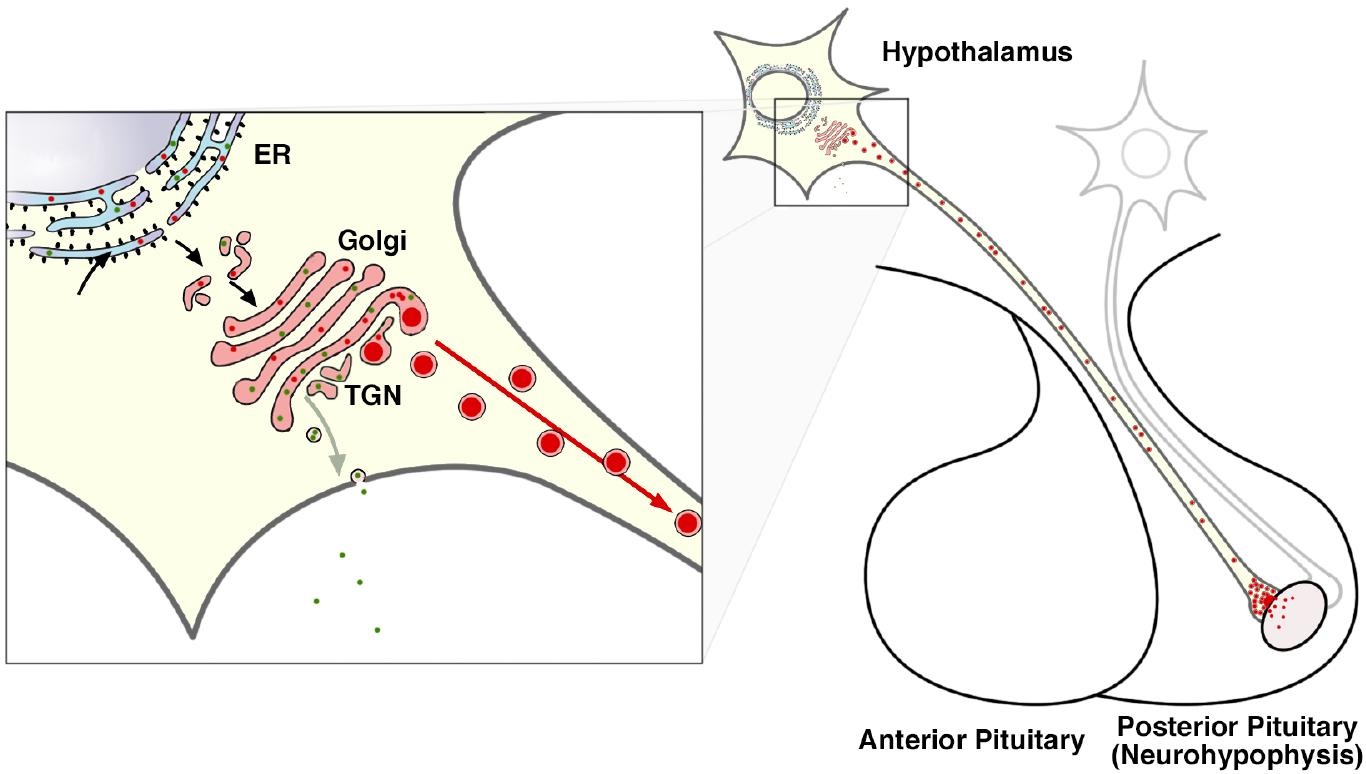


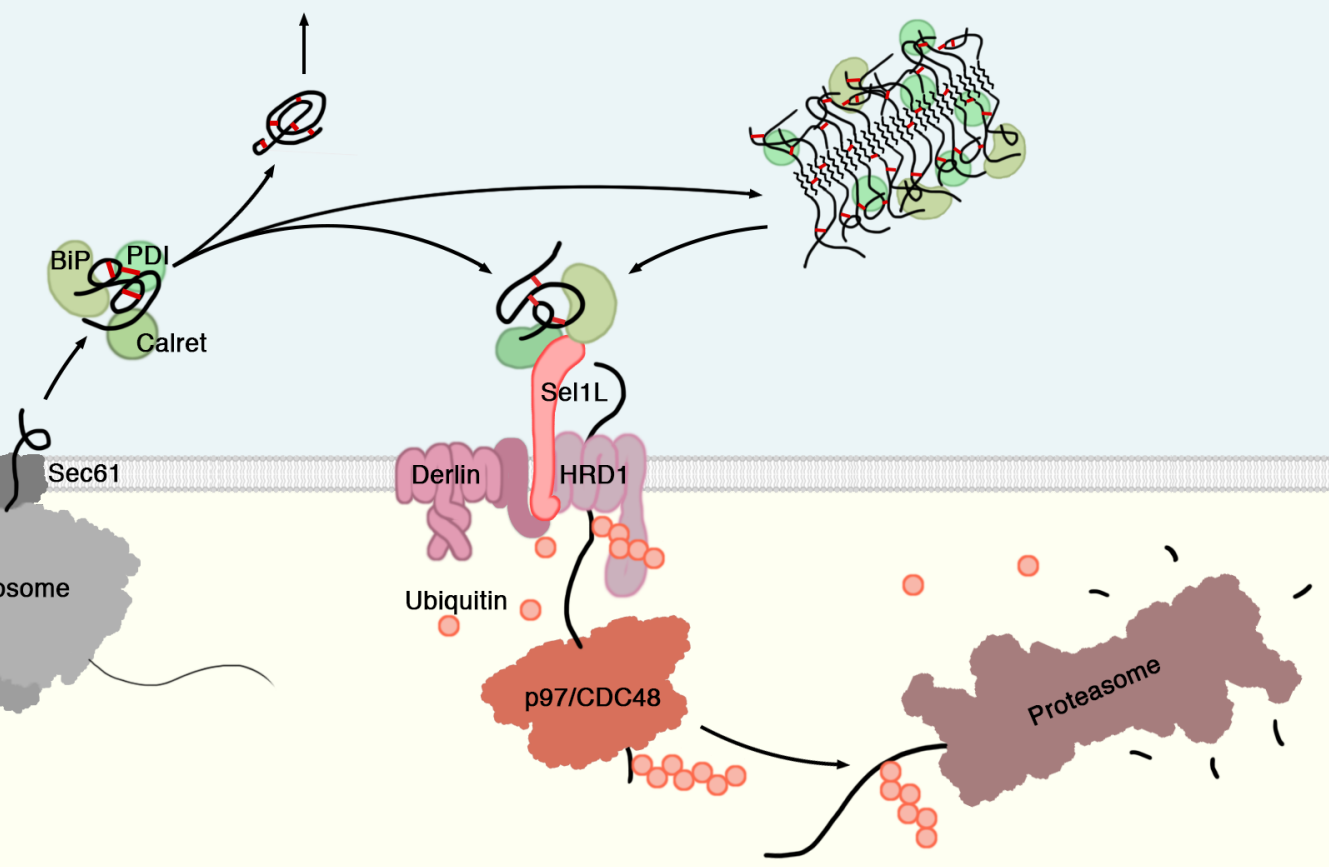




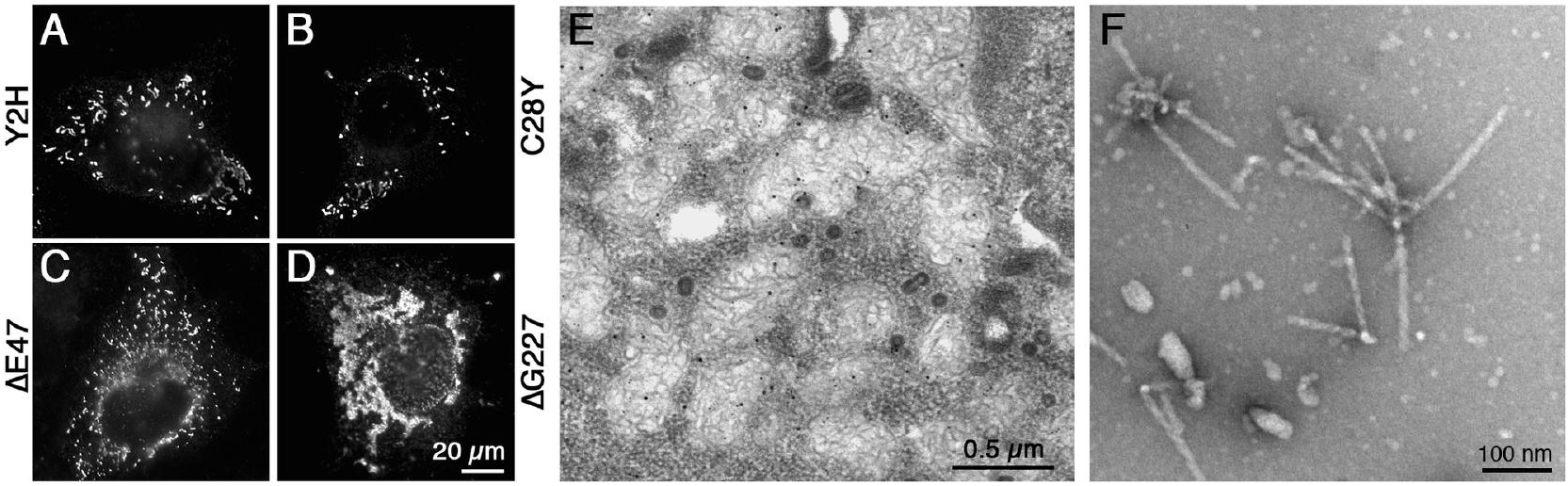




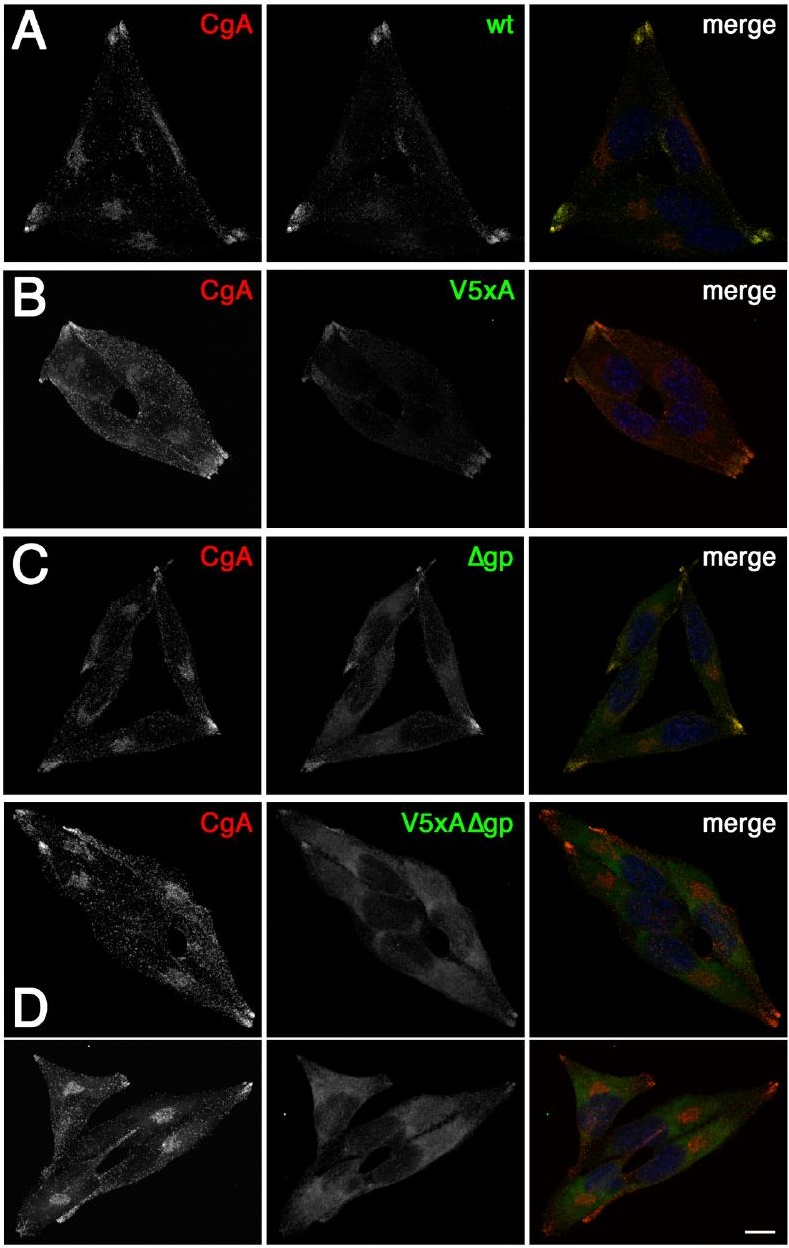


Table 1: Differential diagnosis of diabetes insipidus

\begin{tabular}{|c|c|}
\hline DI type & Causes \\
\hline Neurohypophyseal & $\begin{array}{l}\text { - Trauma, including operations } \\
\text { - Granulomatous disorders (sarcoidosis, histiocytosis) } \\
\text { - Neoplastic disease (e.g. malignant metastases, } \\
\text { - germinoma, craniopharyngeoma, pituitary adenoma) } \\
\text { - Infections } \\
\text { - Ischemia (e.g. Sheehan's syndrome) } \\
\text { - Brain edema (e.g. brain death) } \\
\text { - Hemorrhagia } \\
\text { - } \text { erytoimmune disease (e.g. neurohypophysitis, Lupus } \\
\text { - Hengenital malformations } \\
\text { - Idiopathic }\end{array}$ \\
\hline Renal & $\begin{array}{l}\text { - Ischemia (e.g. tubular necrosis; sickle cell crisis) } \\
\text { - Infiltrating disorders (e.g. amyloidosis, sarcoidosis) } \\
\text { - Drug-induced (e.g. Lithium; Aminoglycosides, } \\
\text { - Cisplatin) } \\
\text { - Hypokalaemia } \\
\text { - Hypercalcaemia } \\
\text { - Postobstructive (transient tubular damage) } \\
\text { - Malignancy } \\
\text { - Hereditary } \\
\text { - Idiopathic }\end{array}$ \\
\hline Primary Polydipsia & $\begin{array}{l}\text { - Increased thirst (dipsogenic; e.g.meningitis, } \\
\text { sarcoidosis, multiple sclerosis) } \\
\text { - Excessive habitual drinking (psychogenic; e.g. } \\
\text { schizophrenia, obsessive-compulsive disorder) }\end{array}$ \\
\hline Gestational & $\begin{array}{l}\text { - Increased AVP degradation by placental } \\
\text { vasopressinase }\end{array}$ \\
\hline
\end{tabular}


Table 2: Forms of hereditary diabetes insipidus

\begin{tabular}{|c|c|c|c|c|}
\hline DI type & $\begin{array}{l}\text { Affected } \\
\text { Gene }\end{array}$ & $\begin{array}{l}\text { Chromosomal } \\
\text { Location }\end{array}$ & $\begin{array}{l}\text { Mode of } \\
\text { Inheritance }\end{array}$ & $\begin{array}{l}\mathrm{OMIM}^{*} \\
\text { Entry }\end{array}$ \\
\hline \multirow{4}{*}{ Neurohypophyseal } & $\begin{array}{l}\text { AVP } \\
\text { (Antidiuretic } \\
\text { hormone) }\end{array}$ & $20 p 13$ & $\begin{array}{l}\text { - Autosomal } \\
\text { dominant } \\
\text { (most } \\
\text { common) } \\
\text { - Autosomal } \\
\text { recessive } \\
\text { (very rare) }\end{array}$ & $\begin{array}{l}125700 ; \\
192340\end{array}$ \\
\hline & Unknown & Xq28 & - X-linked & n.l. ${ }^{* * *}$ \\
\hline & $\begin{array}{l}\text { WFS-1 } \\
\text { (Wolframin) }\end{array}$ & $4 p 16.1$ & $\begin{array}{l}\text { - } \begin{array}{l}\text { Autosomal } \\
\text { recessive }\end{array}\end{array}$ & 222300 \\
\hline & $\begin{array}{l}\text { PCSK1 } \\
\text { (Prohormone } \\
\text { Convertase } \\
\text { Subtilisin/ } \\
\text { Kexin-type 1) }\end{array}$ & $5 q 15$ & $\begin{array}{l}\text { - Autosomal } \\
\text { recessive }\end{array}$ & $\begin{array}{l}162150 ; \\
600955\end{array}$ \\
\hline \multirow[b]{2}{*}{ Nephrogenic } & $\begin{array}{l}\text { AVPR2 (AVP } \\
\text { type 2 } \\
\text { receptor) }\end{array}$ & Xq28 & $\begin{array}{l}\text { X-linked } \\
\text { (most } \\
\text { common) }\end{array}$ & 304800 \\
\hline & $\begin{array}{l}\text { AQP-2 } \\
\text { (Aquaporin-2) }\end{array}$ & $12 q 13.12$ & $\begin{array}{l}\text { - Autosomal } \\
\text { dominant } \\
\text { - Autosomal } \\
\text { recessive }\end{array}$ & 107777 \\
\hline
\end{tabular}

* OMIM; Online Mendelian Inheritance in $\mathrm{Man}^{\circledR}$; https://omim.org ${ }^{* *}$ the recessive mutation P7L (reference \{Willcutts, 1999 \#73\}) is listed in OMIM entry 192340

${ }^{* * *}$ n.l.; not listed 